Indonesian Journal of Nutrition and Dietetics Vol. 5, Issue 2, 2017: 82-87
Available online at: http://ejournal.almaata.ac.id/index.php/IJND DOI : http://dx.doi.org/10.21927/ijnd.2017.5(2).82-87

\title{
Kawista biscuit increased body weight of children under five
}

\author{
Metty $^{1}$, Inayah $^{1}$ \\ ${ }^{1}$ Department of Nutrition, Faculty of Health, Universitas Respati, Yogyakarta, Indonesia \\ ${ }^{*}$ Corresponding author : mettyiskandar@gmail.com
}

\begin{abstract}
Background: Underweight in children under five was a nutritional problem that is often caused by inadequate food intake. Underweight could occur at 6-59 months or should had supplemental feeding and supplementary foods. Supplementary foods have contribute energy to the nutritional adequacy of children under five.

Objectives: To know the effectiveness of kawista biscuits in increasing of bodyweight children under five in Gondokusuman II Primary Health Care.

Methods: Subjects were underweight with the aged of 12-59 months, as much as 19 children. The study was conducted in the working area of Gondokusuman II Primary Health Center Yogyakarta City. This study was quasi experimental with purposive technique sampling. The effectiveness of biscuit kawista a was analysed by paired t-test.

Results: Based on the results of effectiveness test of biscuit kawista for 2 weeks showed significant changes in body weight children $(p=0.000)$ as much as $0.29 \mathrm{~kg}$.

Conclusion: kawista biscuit was significantly increase the weight of children under five who suffer from malnutrition.
\end{abstract}

KEYWORDS: kawista biscuit (Limonia acidissima), underweight, gain weight

\section{INTRODUCTION}

Prevalence of underweight children under five in District of Yogyakarta reach $8.17 \%$ from total $78,43 \%$ children under five that weighed at health center of Yogyakarta city. The number of malnourished children under five in Puskesmas Gondokusuman II amounted to 40 children, this number accounted for $3.2 \%$ of the prevalence of underweight children under five in the district of Yogyakarta (1).

The government's program to increase underweight is by supplementary feeding (PMT). Supplementary feeding for 1 month can increase underweight children under five (2). Provision of biscuits tempeh date for 1 month affects the nutritional status of children (3). Previous research by using tempeh biscuits also shows that supplementary feeding can increase nutritional weight less than $0.2 \mathrm{~kg}$ in 14 days (4).

The community wants the PMT to be a practical product, available in all sizes, and easily accessible anywhere. The types of products that meet these criteria are biscuit (6). Biscuits are crunchy pastries, thin, flat (flattened), and usually small (5).

Utilization of kawista as local food can be improved through the development of processed products. Product development needs to be directed to create a new product that has some properties of interest to the community. Dry cake is one type of snack / small is very popular in both urban and rural communities. The shape and taste of the pastry vary widely, depending on the additional ingredients used (7). Utilization of kawista as an additional food product can reduce the use of wheat flour.

Kawista fruit from Rembang can be eaten directly or usually processed in various commodities such as syrup, dodol, jam and madumongso, because it has a distinctive aroma and taste $(8,9)$. Making biscuits with the addition of kawista flour contains high antioxidants (10).

Utilization of kawista fruit ranging from fruit and seed. Each $100 \mathrm{~g}$ of fruit meat and its seeds contain $64.2 \mathrm{~g}$ of water, $7.1 \mathrm{~g}$ protein, $3.7 \mathrm{~g}$ fat, 18.1 
$\mathrm{g}$ of carbohydrate, $5 \mathrm{~g}$ fiber, $130 \mathrm{mg}$ of calcium, 110 $\mathrm{mg}$ phosphorus, and $0.48 \mathrm{mg}$ of phosphate (11). Research suggests that kawista contains flavonoids, glycosides, saponins and tannins, containing coumarin and tyramine derivatives $(12,13,14)$. The energy of $300 \mathrm{cal}$ in the supplementary diet can increase the weight of underweight children under five (15), while the percentage of protein $15 \%$ of the total energy can improve the nutritional status of infants (16). Based on the content of these nutrients kawista fruit is very beneficial for health, especially for children who are in the process of growing flowers. Another benefit of kawista fruit is as a traditional medicine of liver disease, wound, skin cancer, breast cancer, anti hyperglycemia and antioxidant activity (17).

The nutrient content of kawista fruit has the potential to be used as substitute for peanuts and soybeans in the manufacture of cookies (biscuits), because in kawista contains fiber higher than peanuts and soybeans, and high enough protein, and other nutrients (18). Proper and practical processing of materials will produce products of value. Researchers have utilized kawista fruit from Rembang to be used as substitution materials for making biscuits kawista. Kawista biscuits that have been made by researchers can be given as additional feeding in improving weight in underweight children under five in work area of Primary Health Center Gondokusuman II, Yogyakarta.

\section{MATERIALS AND METHODS}

The type of research used here is quasi experimental because it wants to know the weight gain before and after being given intervention. Sampling technique with purposive sampling on the respondent children aged 12-59 months, with inclusion criteria that has no history of low birth weight, not premature, and has no infectious diseases. Underweight children under five data obtained from Primary Health Center Gondokusuman II. The sample in the study was 19 balita less nutrient (BB / U), using mean body weight and standard deviation treatment group (1.2846 \pm 0.40589$)$ and control (0.4250 \pm 0.46975$)$ (19), and calculated using Lemeshow formula. Test the effectiveness analysis of biscuit kawista on balita by using paired t-test.

Kawista biscuits have been made by researchers and analyzed physical properties, organoleptic test, and proximate levels. Biscuits kawista then given to know the effectiveness to increase weight of children under five less nutrition (BB / U). Kawista biscuit is done for two weeks, 4 pieces $(50 \mathrm{~g})$ per day with energy content $427.6 \mathrm{cal}$ / $100 \mathrm{~g}$ and protein $7.45 \mathrm{~g} / 100 \mathrm{~g}$. In this study also conducted measurement of food intake by using recall $3 \times 24$ hours to know the percent contribution of biscuit kawista consumed.

\section{RESULTS}

\section{Characteristics of research subjects}

Subjects in this study were all children under five with underweight (age 12-59 months) in the Primary Health Center Godokusuman II, Yogyakarta.

Table 1. Distribution of characteristic frequency of research subjects

\begin{tabular}{ccc}
\hline Characteristic & $\mathbf{n}$ & $\%$ \\
\hline Sex of children under five & & \\
Male & 9 & 47.4 \\
Female & 10 & 52.6 \\
Years (Month) & & \\
$12-36$ & 9 & 47.4 \\
$37-59$ & 10 & 52.6 \\
\hline Total & 19 & 100 \\
\hline
\end{tabular}

Based on the data above that most of the underfives malnutrition female less than 10 people $(52.6 \%)$ and 9 people $(47.4 \%)$ man. Underweight age ranged from 37-59 months as many as 10 people $(52.6 \%)$ and age $12-36$ as many as 9 people (47.4\%).

\section{Univariate Analysis \\ Child Weight Loss Less}

Based on Table 2 it can be seen that the mean early body weight of underweight children less than $10.45 \pm 1.41 \mathrm{~kg}$. While the mean final weight of underweight children less nutrition after given biscuit kawista for 2 weeks amounted to $10.74 \pm 1.37 \mathrm{~kg}$. 
Table 2. Weight loss child nutrition

\begin{tabular}{ccccc}
\hline \multirow{2}{*}{ Weight } & \multicolumn{4}{c}{ Average } \\
\cline { 2 - 5 } & Min & Maks & Mean & SD \\
\hline Early Weight & 8.60 & 13.00 & 10.45 & 1.41 \\
Late Weight & 8.80 & 13.40 & 10.74 & 1.37 \\
\hline
\end{tabular}

\section{Kawista Biscuit Intake}

Here below is the daily average intake of biscuit kawista by under-nutrition less:

Table 3. Intake of kawista biscuits

\begin{tabular}{ccccc}
\hline Intake of & \multicolumn{4}{c}{ Average daily intake of kawista } \\
\cline { 2 - 5 } Kawista Biscuits & Min & Maks & Mean & SD \\
\hline Energy (kal) & 30.64 & 126.40 & 71.77 & 28.34 \\
Protein (g) & 0.57 & 2.36 & 1.34 & 0.53 \\
Fat (g) & 1.57 & 6.48 & 3.68 & 1.45 \\
Carbohydrate (g) & 3.71 & 15.32 & 8.70 & 3.44 \\
Fiber (g) & 0.71 & 2.95 & 1.67 & 0.66 \\
Fe (g) & 0.00 & 0.01 & 0.0005 & 0.002 \\
\hline
\end{tabular}

The average daily intake of kawista biscuits for 2 weeks includes energy of $71.77 \pm 28.34$, protein $1.34 \pm 0.53$, fat $3.68 \pm 1.45$, carbohydrates $8.70 \pm$ 3.44 , fiber $1.67 \pm 0.66$, and Fe $0.0005 \pm 0.002$.

\section{Food Intake}

Here is the average table of intake of food consumed less than $3 \times 24$ hour nutrition:

Table 4. Food intake

\begin{tabular}{ccccc}
\hline \multirow{2}{*}{ Food Intake } & \multicolumn{4}{c}{ Average } \\
\cline { 2 - 5 } & Min & Maks & Mean & SD \\
\hline Energy & 260.23 & 1095.33 & 6.06 & 187.07 \\
Protein & 8.30 & 39.93 & 23.50 & 8.25 \\
Fat & 10.47 & 37.87 & 22.48 & 6.95 \\
Carbohydrate & 33.83 & 149.93 & 78.91 & 31.90 \\
Fiber & 1.07 & 5.23 & 2.61 & 1.10 \\
Fe & 1.13 & 9.83 & 3.83 & 2.68 \\
\hline
\end{tabular}

Based on the data above the food intake obtained from recall $3 \times 24$ hours, showed that the average daily food intake of children under five nutrition such as energy 6.06,06 $\pm 187.07,23.50 \pm$ 8.25 protein, $23.50 \pm 8.25$ fat, $78.91 \pm$ carbohydrate 31.90 , fiber $2.61 \pm 1.10$, and Fe $3.83 \pm 2.68$.

\section{Food intake and kawista biscuits}

Here is the daily average of kawista biscuit donation in the mean of less nutrition.

Based on the data above that biscuit kawista can contribute $10.58 \%$ energy, $1.34 \%$ protein, $14.07 \%$ fat, 9.93 carbohydrate, 38.3 fiber, and 0.01 Fe.

\section{Bivariate Analysis}

Here is the data on weight gain less nutrition children after the treatment of biscuit kawista for 2 weeks:

Table 6. Increase in weight of malnourished children

\begin{tabular}{ccc}
\hline Weight Gain & Means \pm SD & P \\
\hline Early Weight & $10.45 \pm 1.41$ & 0.000 \\
Late Weight & $10.74 \pm 1.37$ & \\
\hline Difference & 0.29 & \\
\hline
\end{tabular}

Based on the results of the analysis in Table 6 shows that after treatment in the form of kawista biscuits can increase weight significantly ( $p=$ $0.000)$.

\section{DISCUSSIONS}

\section{Characteristics of Respondents}

Respondents in this study were 19 under five children with malnutrition age 12-59 months who are in the area of Primary Health Centers Gondokusuman II. Based on the results obtained (Table 5) shows that the number of malnourished men and women does not differ greatly, as well as

Table 5. Percentage of kawista biscuit contribution

\begin{tabular}{ccccccc}
\hline \multirow{2}{*}{ Intake } & \multicolumn{7}{c}{ Average } \\
\cline { 2 - 7 } & Energy & Protein & Fat & KH & Fiber & Fe \\
\hline Total Intake & 678.22 & 24.83 & 26.16 & 87.61 & 4.29 & 3.83 \\
Feeding Kawista & 71.77 & 1.34 & 3.68 & 8.70 & 1.67 & 0.0005 \\
\% Contribution kawista & 10.58 & 5.40 & 14.07 & 9.93 & 38.93 & 0.01 \\
\hline
\end{tabular}


by age group. Based on the food intake data (Table 5), the average daily food intake of $678.22 \mathrm{cal}$ and $24.83 \mathrm{~g} /$ day protein. It can be seen that the intake of food consumed daily does not meet the adequacy of underfive age (12-59 months) which should be energy reaching $1125-1600 \mathrm{kcal} /$ day and protein 25-39g/day.

Based on the age range 12-24 months is said to be vulnerable due to the transition period from infant to child, so that children are susceptible to infection or nutritional status disorder. At that age children also experience many dietary changes (20). Results recall $3 \times 24$ hours showed less variety of foods consumed by toddlers. This can be because the toddler's mother does not have enough skills to cultivate diverse foods. Factors that cause less nutritional state is improper behavior in choosing and giving food to the child (21).

\section{Univariate Analysis}

The results of weight analysis (Table 2) showed that the mean of underweight children after being given biscuits for 2 weeks had increased by $0.29 \mathrm{~kg}$. This increase shows that kawista biscuits at least contribute energy for infant intake of $10.58 \%$ calories/day and protein $5.48 \%$ calories/day.

The result of proximate test shows that kawista biscuit contains energy equal to $427.6 \mathrm{cal} / 100 \mathrm{~g}$ and $7.5 \% / 100 \mathrm{~g}$, so it can be calculated that kawista biscuit of 4 pieces contains $214.7 \mathrm{cal} / 50 \mathrm{~g}$ and protein $3.75 \% / 50 \mathrm{~g}$. Based on the theory of supplementary feeding to under-fives according to the Ministry of Health, kawista biscuits have met the supplementary feeding of pre-school age children with energy ranging from 200 to 300 calories and 5 to 8 grams of protein. The low intake of kawista biscuits (Table 3 ) is due to the boredom of children under five consuming kawista biscuits, so that biscuits are not consumed by toddlers every day. Likewise, the contribution of the contribution of kawista biscuit showed low. Boredom on food becomes one of the reasons toddlers hard to eat. This is the case in previous studies that the longer the $\mathrm{BMC}$ biscuits and the slightly harder biscuit texture make the child bored (22).

\section{Bivariate Analysis}

Based on paired-t test statistic shows that there is less significant increase of nutritional weight less after given biscuit kawista for 2 weeks with result of increase equal to $0.29 \mathrm{~kg}$. This increase occurs in PMT administered, indicating that within 2 weeks of PMT delivery of tempe nugget may increase body weight by $0.20 \mathrm{~kg}$ (23). Kawista biscuits contain high energy in $100 \mathrm{~g}$ of $427.6 \mathrm{cal}$. Weight gain can occur due to consumption kawista in the first week is quite large by the subject of research. Most subjects spend 4 copies of kawista biscuit equivalent to 214.7 $\mathrm{cal} / 50 \mathrm{~g}$. The amount of energy per day generated from $50 \mathrm{~g}$ kawista biscuits has contributed energy from PMT is 200 calories.

The direct causing factor of malnutrition is food intake. Toddlers with underweight nutrition are children under five who have intake of energy and protein inadekuat (24). When seen the average of food intake of research subjects is quite low for children aged 12-59 months. Toddlers with inadequate dietary intake are at risk 5 times to experience less nutritional status compared with children under five who have sufficient nutritional intake (25). Supplementary feeding is one way to increase the caloric intake of food given as a distraction.

\section{CONCLUSIONS AND RECOMMENDATIONS}

Kawista biscuits given to underweight children less than 2 weeks effective weight gain significantly $(p=0.000)$. Further research needs to be done by familiarizing children taking kawista biscuits as additional food for longer periods of time, to gain more adequate weight. Need further research related antioxidants in biscuit in children under five malnutrition

\section{ACKNOWLEDGMENTS}

We would like to thank Ristekdikti for funding this research, as well as to the Research and Community Service Center of Universitas Respati Yogyakarta who has assisted in the research process. 


\section{REFERENCES}

1. Dinas Kesehatan RI, 2013. Profil Kesehatan Indonesia Tahun 2013. Kemenkes RI 2014. Jakarta.

2. Rizky O, Wirjatmadi B, Ardiani M. (2015). Pengaruh Pemberian Makanan Tambahan Biskuit dan Bolu Tepung Tempe terhadap Peningkatan Berat Badan dan Tinggi Badan pada Balita Gizi Kurang. Jurnal IImiah Kedokteran. Vol 4(1), hal 16-24.

3. Famitalia D. (2011). Pengaruh Pemberian Biskuit Tempe Kurma terhadap Perubahan Status Gizi Balita di Kelurahan Terpilih di Depok Tahun 2010.

4. Maryam, Arfiana, dan Sukini T. (2017). Efektivitas Konsumsi Nugget Kedelai terhadap Kenaikan Berat Badan Balita Gizi Kurang. Jurnal Kebidanan.Vol 6(12).

5. Pamungkas, Esti .S. (2008). Pemanfaatan Tepung Ubi Kayu dan Tepung Biji Kecipir Sebagai Substitusi Terigu Dalam Pembuatan Cookies. Skripsi. Universitas Sebelas Maret Surakarta.

6. Mayang dan Anindyajayanti. 2007. Formulasi dan Optimasi Produk Biskuit Berbahan Baku Sagu Ubi Jalar dan Kacang Hijau. (http://digillib.ac.id/ colection/skripsi), (Diakses 12 April 2010).

7. Suarni. (2004). Pemanfaatan Tepung Sorgum Untuk Produk Olahan. Jurnal Litbang Pertanian, 23(4).

8. Apriyanto A dan Kumara B. (2004). Identifikasi Character Impact Odorants Buah Kawista (Feronia limonia). Jurnal.Teknol. dan Industri Pangan, Vol XV(1).

9. Nugroho I.A. 2012. Keragaman Morfologi dan Anatomi Kawista (Limonia Acidissima L.) di Kabupaten Rembang. Skripsi. Institut Pertanian Bogor.

10. Ilango, K and Chitra, V. (2010). Wound Healing and Anti-oxidant Activities of the Fruit Pulp of Limonia Acidissima Linn (Rutaceae) in Rats. Trop J Pharm Res, June 2010; 9 (3): 223.

11. Gopalan C., Sastri B.V.R., Balasubramanian S.C. 2012. Nutritive Value of Food Indians. National Institute of Nutrition, ICMR, Hyderabad, Offset Press.
12. Saima $Y$, Das AK, Sarkar KK, Sen AK and Sur $P$ (2000). An antitumor pectic polysaccharide from Feronia limonia. International Journal of Biology and Macromolecule, 27: 333-335.

13. Adikaram NKB, Yamuna A, Lesliegunatilaka A, Ratnayuke BM, Kithsiri EM and Wijeratne (2007). Antifungal activity, acid and sugar content in wood apple (Limonia acidissima) and their relation to fungal development. Plant Pathology, 38: 258-265.

14. Parthasarathi G, Prabal S, Srabani D, Swapnadip T, Kokke WCMC and Akihisa T (1991). Tyramine Derivatives from the Fruit of Limonia acidissima. Journal of Natural Products, 54: 1389-1393.

15. Rizky I.O, Wirjatmadi B, Adriani M. (2015). Pengaruh Pemberian Makanan Tambahan Biskuit dan Bolu Tepung Tempe terhadap Peningkatan Berat Badan dan Tinggi Badan pada Balita Gizi Kurang Tahun 2015. Jurnal "IImiah Kedokteran", Vol 4(1):16-24.

16. Hörnell A, Lagström $H$, Lande $B$, Thorsdottir I. Protein intake from 0 to 18 years of age and its relation to health: a systematic literature review for the 5th Nordic Nutrition Recommendations. Food Nutr Res [Internet]. 2013;57:1-42. Available from: http://www.pubmedcentral.nih. gov/articlerender. fcgi?artid=3664059\&tool=pm centrez\&rendertype=abstract

17. Qureshi AA, Kumar KE and Omer S (2010). Feronia limonia - A path less travelled. International Journal of Research in Ayurveda and Pharmacy, 1(1): 98-106.

18. Azizah, Nur., dkk. (2013). Sifat Fisik, Organoleptik, dan Kesukaan Yoghurt Drink dengan Penambahan Ektrak Buah Nangka. Jurnal Apliksi Teknologi Pangan Vol 2 (3).

19. Famitalia D. (2011). Pengaruh Pemberian Biskuit Tempe Kurma terhadap Perubahan Status Gizi Balita di Kelurahan Terpilih di Depok Tahun 2010.

20. Adriani dan Wirjatmadi. 2012. Peranan Gizi dalam Siklus Kehidupan. Kencana. Jakarta.

21. Asrar M, Hadi H, Boediman D. (2009). Pola Asuh, Pola Makan, Asupan Zat Gizi, dan Hubungannya dengan Status Gizi Anak Balita 
Masyarakat Suku Nuaulu di Kecamatan Amahai Kabupaten Maluku Tengah Provinsi Maluku. Jurnal Gizi Klinik Indonesia, Vol. 6(2) : 84-94.

22. Widiada I.G.N., dan Sofiyatin R. (2013). Efektifitas Pemberian Biskuit Bmc Terhadap Peningkatan Berat Badan Anak Gizi Kurang Usia 12-24 Bulan Diwilayah Kerja Puskesmas Dasan Cermen Cakranegara. Vol.7(2).

23. Sutomo, B. (2008). Sukses Wirausaha Kue Kering. Jakarta : Kriya Pustaka
24. Purwaningrum S dan Wardani Y. (2012). Hubungan Antara Asupan Makanan dan Status Kesadaran Gizi dengan Status Gizi Balita di Wilayah Kerja Puskesmas Sewon I, Bantul. Jurnal Kesehatan Masyarakat Vol. 6 No. 3,

25. Nuzula F, Oktaviana M.N, Anggari, R.S. (2017). Analis terhadap Faktor-faktor Penyebab Gizi Kurang pada Balita di Desa Banyuanyar Kecamatan Kalibaru Banyuwangi. Akademi Kesehatan 'Rustida”. 